\title{
НОВЫЙ ПОДХОД К ПОЛУЧЕНИЮ АНИЛОВТЕРПЕНОИДНЫХ КЕТОНОВ В НАПРАВЛЕННОМ КОНСТРУИРОВАНИИ СТРУКТУРНЫХ АНАЛОГОВ БРОМАНТАНА
}

\section{А.А. Вернигора, И.А. Новаков, М.Б. Навроцкий, А.В. Давиденко, Р.В. Брунилин}

ФГБОУ ВО Волгоградский государственный технический университет, 400005, Российская Федерация,Волгоград, пр. имени Ленина, 28.

DOI: 10.19163/MedChemRussia2021-2021-243

E-mail:vernigoraa@vstu.ru

В рамках выполнения работ по направленному конструированию новых структурных аналогов синтетического адаптогена - Бромантана, с прицелом на снижение гепатотоксических свойств прототипа, был предложен новый подход [1, 2] к получению ключевых интермедиатов синтеза - аниловтерпеноидных кетонов. В основе данного подхода лежит реакция конденсации соответствующего кетона - камфоры или фенхона, с соответствующим ариламином в присутствии (i-PrO) $)_{4}$ Ті и комплексного катализатора $\left[(i-\operatorname{PrO})_{2} \mathrm{Ti}(\mathrm{OTf})_{2}\right] \bullet(i-$ $\mathrm{PrOH})_{2}$ [3], полученного insitu:

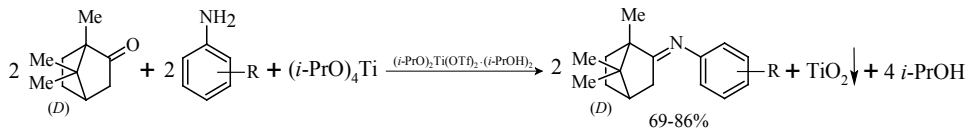

где: $\mathrm{R}=\mathrm{H}$; 2-Me; 2-Et; 3-MeO; 4-MeO; 4-Br

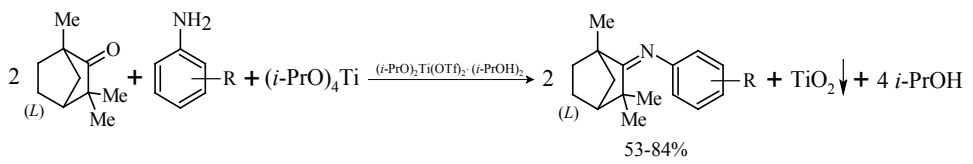

где: $\mathrm{R}=\mathrm{H}$; 3-МеO; 4-МеO; 4-EtO; 3,5-Ме

Установлено, что этот подход позволяет получить анилы, недоступные другими методами. Попытки восстановления полученных соединенийс использованием $\left.\mathrm{AlH}_{3}, \mathrm{Li}_{\mathrm{LllH}}\right]$ и в условиях реакции Швенка-Папа к успеху не привели. В то же время, восстановление этих соединений $\mathrm{NaBH}_{4}$ и $\mathrm{NiCl}_{2} \cdot 6 \mathrm{H}_{2} \mathrm{O}$ в $\mathrm{MeOH}$ протекает успешно, но сопровождается гидрогенолизом связи углерод-галоген в случае производных галогенированных анилинов. Боран, полученный insitu, даёт стабильные продукты присоединения. Попытка восстановления Zn в АсОН сопровождается разложением исходного анила.

\section{Литература}

[1] Патент 2020140906 РФ МПК С07С 249/02, С07С 251/20. Способ получения аниловD-камфоры. И.А. Новаков, Р.В. Брунилин, А.А. Вернигора, А.В. Давиденко, П.П. Дешевов, М.Б. Навроцкий-ВолгГТУ. 2020.

[2] Заявка на патент РФ 2020140936. Способ получения аниловL-фенхона. И.A. Новаков, Р.В. Брунилин, А.А. Вернигора, А.В. Давиденко, П.П. Дешевов, М.Б. Навроцкий. Дата поступления 11.12.2020.

[3] Y. Motoyama, M. Tanaka, K. Mikami, InorganicaChimicaActa. 1997, 256, 2, 161-163.

$$
-243-
$$

